\title{
CAPITALISMO E NATUREZA: DESTRUIÇÃO SOCIOAMBIENTAL E EXPLORAÇÃO DA FORÇA DE TRABALHO
}

\author{
CAPITALISMO Y NATURALEZA: DESTRUCCIÓN SOCIOAMBIENTAL Y \\ EXPLORACIÓN FUERZA DE TRABAJO
}

\section{CAPITALISM AND NATURE: SOCIO-ENVIRONMENTAL DESTRUCTION AND EXPLOITATION OF THE WORKFOCE}

DOI: http://doi.org/10.9771/gmed.v13i2.44176

Amanda Aparecida Marcatti ${ }^{1}$

Hormindo Pereira de Souza Junior ${ }^{2}$

Resumo: A sociabilidade capitalista produz desastres socioambientais de proporções gigantescas. O nível atual da exploração da força de trabalho e da natureza potencializa todos os processos de apropriação privada da riqueza e, ao mesmo tempo, produz adoecimentos socioambientais. Discutimos neste artigo a gênese da ação humana de conteúdo abertamente autodestrutivo das dimensões inorgânicas, orgânicas e sociais da natureza e a potência transformadora das lutas anticapitalista que unificam exploração da força de trabalho, as dimensões inorgânicas e orgânicas da natureza em um mesmo patamar.

Palavras-chave: capitalismo. Natureza. Exploração. Destruição socioambiental.

Resumen: La sociabilidad capitalista produce desastres socioambientales de proporciones gigantescas. El nivel actual de explotación de la mano de obra y la naturaleza potencia todos los procesos de apropiación privada de la riqueza y, al mismo tiempo, produce enfermedades socioambientales. Discutimos en este artículo la génesis de la acción humana con contenido abiertamente autodestructivo de las dimensiones inorgánica, orgánica y social de la naturaleza y el poder transformador de las luchas anticapitalistas que unifican la explotación de la fuerza de trabajo, las dimensiones inorgánica y orgánica de la naturaleza al mismo tiempo y nivel.

Palabras clave: capitalismo. Naturaleza. Exploración. Destrucción socioambiental.

Abstract: Capitalist sociability produces socio-environmental disasters of gigantic proportions. The current level of exploitation of the workforce and nature enhances all processes of private appropriation of wealth and, at the same time, produces socio-environmental illnesses. We discuss in this article the genesis of human action with openly selfdestructive content of the inorganic, organic and social dimensions of nature and the transformative power of the anti-capitalist struggles that unify exploitation of the workforce, the inorganic and organic dimensions of nature at the same level.

Keywords: capitalism. Nature. Exploration. Socio-environmental.

\section{Introdução}

A capacidade humana de transformar a natureza e de nos autotransformamos nos forja como ser social. Sem a mediação fundamental do trabalho como atividade humana, viveríamos como os demais seres vivos do planeta, incapazes de conduzirmos nossa própria história e determinados por nossas 
condições biológicas. Por isso, a existência humana está intimamente vinculada à capacidade adquirida pelo ser social de transformação da natureza em sua universalidade. Através do trabalho, transformamos a natureza e nos autotransformamos, satisfazendo, assim, as necessidades biológicas, sociais e históricas para a produção/reprodução da vida humana (SOUZA JUNIOR, 2008).

O trabalho é, portanto, a atividade vital da existência humana, a mediação com a natureza que possibilita o salto ontológico fundante do ser social, nos diferenciando, irrevogavelmente, do conjunto dos demais seres vivos existentes. O momento teleológico do trabalho "implica numa finalidade e, portanto, numa consciência que estabelece fins", ou seja, uma finalidade pela qual se deve transformar a natureza (LUKÁCS, 1986/s.d, p. 9). Assim, "só é lícito falar do ser social quando se compreende que a sua gênese, o seu distinguir-se da sua própria base, o processo de tornar-se algo autônomo, se baseiam no trabalho, isto é, na contínua realização de posições teleológicas.” (LUKÁCS, 1986/s.d., p. 13).

Contudo, o fato de sermos seres sociais não elimina a dimensão inorgânica e orgânica da vida humana. Isso "significa que: a natureza é o seu corpo, com o qual ele tem que ficar num processo contínuo para não morrer" (MARX, 2004, p. 84). Ademais, o "ser humano é um ser histórico e social criativo, que desenvolveu a capacidade de conhecer a natureza e aplicá-la em seu cotidiano visando a sua liberdade" (MENEZES, 2016, p. 28).

Por essa razão, a relação humana com a natureza se dá numa perspectiva dialética, em "que a vida física e mental do homem está interconectada com a natureza, não tem outro sentido, senão que a natureza está interconectada consigo mesmo, pois o homem é uma parte da natureza” (MARX, 2004, p. 84). Entretanto, a efetivação da sociabilidade capitalista demarca a relação de estranhamento entre a sociedade e natureza, cindindo em instâncias privadas e dicotômicas a natureza e o humano.

\footnotetext{
Sociologicamente, a relação entre o ser humana e a natureza sempre foi objeto de muitas especulações e reificações. As cosmologias primitivas, assim como as cosmologias indígenas vigente em diversas sociedades atuais, procuram na natureza diversas explicações para o desenvolvimento histórico e social. Há uma alteridade, uma vida própria da natureza regendo a própria vida social e uma analogia entre o funcionamento da natureza e da sociedade. [...] Os gregos antigos também debatiam a cosmologia e, dividindo o mundo natural entre o ar e água, começaram a ver a natureza na sua forma não sobrenatural. Já o cristianismo coloca o ser humana acima da natureza. Na modernidade, encontramos a cisão no ser humano entre o corpo e espírito, homem e natureza, e essas seriam as marcas constitutivas de nosso tempo. (MENEZES, 2016, pp. 36-37).
}

Portanto, é importante compreendermos como a sociedade capitalista baseada na propriedade privada dos meios de produção; na divisão social do trabalho; e no trabalho assalariado gera a negação da dimensão natural do ser social como parte do processo da alienação do trabalho. A ideologia do desenvolvimento capitalista produziu uma racionalidade que adentrou o pensamento ocidental desde o iluminismo, mas que teve sua expressão máxima na segunda metade do século XIX, com as conquistas tecnológicas obtidas pela Revolução Industrial. Expandindo para o mundo, uma concepção universal de civilização, progresso e tecnologia. Deste modo, alcançamos que a alienação do trabalho na sociedade capitalista produz como ideologia a supremacia humana sobre a natureza - o desenvolvimento do 
capitalista supõe deter total controle sobre as interferências e interações da ação humana sobre a natureza, apartando-se da sua condição natural. Isto é, o desenvolvimento tecnológico e científico na sociedade capitalista apresenta-se ao conjunto da sociedade como produtos neutros do progresso humano, apartados das condições sociais, econômicas, políticas e ambientais em que são produzidos e que geram com o seu uso. Assim, buscamos discutir ao longo desse artigo desde uma crítica marxista da sociedade capitalista a gênese da ação humana de conteúdo abertamente autodestrutivo das dimensões inorgânicas, orgânicas e sociais da natureza, tendo como ponto de inflexão para este debate o desenvolvimento tecnológico e científico e a produção do agronegócio. Alçamos que este tema seja essencial diante a crise estrutural do capital, no qual o nível atual de exploração da força de trabalho e da natureza tem potencializado os processos de apropriação privada da riqueza, destruição da natureza e, ao mesmo tempo, produzido adoecimentos socioambientais.

\section{Capitalismo e fetiche da autonomia técnico-científica}

Ao considerarmos a fetichização do desenvolvimento tecnológico e científico, como uma faceta ideológica da sociabilidade capitalista nos parece necessário aos dias atuais, retornamos há uma questão inicial: o que é tecnologia? Resumidamente, a tecnologia pode ser definida como o conjunto de instrumentos e técnicas produzidos socialmente, que modificam a natureza, aprimorando a produtividade do trabalho. Logo, o ser humano, ao buscar intervir na natureza, "conquistou grandes avanços no desenvolvimento científico e tecnológico, indispensáveis à nossa vida e à nossa própria condição da conquista da liberdade, perante as necessidades impostas pela natureza” (MENEZES, 2016, p. 27).

Logo, é indispensável diferenciarmos a capacidade humana de conhecer, agir e transformar a natureza para a sua liberdade, da relação de subordinação da acumulação capitalista que gera o desenvolvimento tecnológico e científico, como aponta Milton Santos (2018, p. 65) ao expor a fábula da globalização capitalista:

É irônico recordar que o progresso técnico aparecia, desde os séculos anteriores, como uma condição para realizar essa sonhada globalização com a mais completa humanização da vida no planeta. Finalmente, quando esse progresso técnico alcança um nível superior, a globalização se realiza, mas não a serviço da humanidade. A globalização mata a noção de solidariedade, devolve o homem à condição primitiva do cada um por si e, como se voltássemos a ser animais da selva, reduz as noções de moralidade pública e particular a um quase nada. O período atual tem como uma das bases esse casamento entre ciência e técnica, essa tecnociência, cujo uso é condicionado pelo mercado. Por conseguinte, trata-se de uma técnica e de uma ciência seletivas. Como, frequentemente, a ciência passa a produzir aquilo que interessa ao mercado, e não à humanidade em geral, o progresso técnico e científico não é sempre um progresso moral. Pior, talvez, do que isso: a ausência desse progresso moral e tudo o que é feito a partir dessa ausência vai pesar fortemente sobre o modelo de construção histórica dominante no último quartel do século XX. 
Cabe ainda incluirmos à caracterização da globalização capitalista como perversidade, a assimetria das tecnologias utilizadas na produção capitalista, que combinam o uso de tecnologias avançadas e rudimentares em diferentes níveis da cadeia produtiva das mercadorias, como é o caso do agronegócio. A produção da soja por exemplo, utiliza tecnologias especializadas no preparo do solo, adubação das sementes transgênicas, aplicação dos agrotóxicos, irrigação da lavoura, colheita mecânica e armazenamento dos grãos.

Entretanto, nesta mesma cadeia produtiva de grãos é comum a morte de trabalhadores rurais nos silos por asfixia. Eles são soterrados por toneladas de soja quando caminham sobre o silo sem a utilização dos equipamentos de segurança como cordas e guinchos, tentando desobstruir o duto que fica entupido com as partículas de soja agregadas. Outros acidentes como a explosão dos silos que contêm grande porção de pó de soja e o soterramento dos trabalhadores podem ocorrer quando as paredes dos armazéns implodem. Esses acidentes de trabalho poderiam ser facilmente evitados com o uso de equipamentos de proteção individual e com o investimento em tecnologias que auxiliem a atividade do trabalhador dentro do silo, entretanto, a vida dos trabalhadores vale menos que os grãos de soja comercializados na bolsa de valores (FELLET, 2018).

Mais um setor do agronegócio que emprega de forma assimétrica a tecnologia é a indústria da carne. Esse setor detém alto nível tecnológico combinado com a superexploração da força de trabalho e degradação da natureza. Na atualidade, a intensificação da produção da proteína animal no Brasil está diretamente vinculada às disputas por terras, ao desmatamento, à contaminação dos recursos hídricos pelos dejetos animais. Além de contribuir para o aumento expressivo do uso de fertilizantes e agrotóxicos agrícolas, uma vez que a alimentação animal usa majoritariamente a soja (IPEN; ABRASCO, 2021).

Segundo o relatório "Climate Change and Land” (Intergovernmental Painel on Climate Change [IPCC], 2019), a agropecuária e o desmatamento responderam por 23\% das emissões de gases de efeito estufa, responsáveis pelo aquecimento global. Especialmente no caso brasileiro, a pecuária tem forte impacto no aquecimento global, dado o histórico da concentração de terras no país. Cerca de $80 \%$ do rebanho bovino no Brasil é criado a pasto, gerando elevados índices de desmatamento para formação de pastagens e lavouras, acentuando o conflito agrário. Além disso, esses animais emitem, durante o processo de fermentação entérica, o gás metano que, juntamente com os processos industriais e a queima dos combustíveis fósseis são os maiores responsáveis pela intensificação do efeito estufa. No Brasil, existe mais gado do que gente, atualmente o país tem o maior rebanho bovino do mundo, são 222 milhões de cabeças de gado para 211 milhões de pessoas (Instituto Brasileiro de Geografia e Estatística [IBGE], 2020).

Ademais, é preciso expor que a produção da carne e seus derivados consomem níveis exorbitantes de água. Para se produzir um litro de leite de vaca, são gastos 1000 litros de água. A produção de um ovo gasta, em média, 200 litros de água, e de 1 kg de queijo, se gastam 5000 litros de água. Somado ao fato, de que a indústria da carne e seus derivados possuem condições de trabalho degradantes e insalubres. Os trabalhos dos frigoríficos estão expostos a uma série de riscos devido ao manejo constante 
de facas, serras e máquinas cortantes em um ritmo alucinado de produção, com movimentos repetitivos, em um ambiente com baixa temperatura, luminosidade e circulação do ar. Acrescido de jornadas exaustivas, baixa remuneração. Muitos estudos ainda relatam que os trabalhadores dos frigoríficos sofrem com lesões musculares causadas por movimentos repetitivos, amputação de membros, depressão e tentativas de suicídio (MARCATTI, 2014).

Outro fato que merece nossa atenção são as condições de produção dos animais para abate e exportação. A maior parte da produção global de carne e seus derivados se dá em regime de confinamento, o que reduz a vida animal a uma lógica fabril. Esses animais vivem apartados de sua condição natural em espaços reduzidos e superlotados. A produção de ovos, por exemplo, normalmente ocorre, no regime de gaiolas de confinamento desconsiderando o bem-estar animal. Para otimizar e reduzir os custos da produção, as galinhas são mantidas em uma gaiola, ainda na fase de cria os pintos têm o bico cortado para evitar o canibalismo resultante do estresse intenso e contínuo a que são submetidas no confinamento. As galinhas passam a vida inteira, cerca de dois anos, em gaiolas até que sejam levadas para o abate sem conseguir abrir as asas, ciscar ou mesmo pisar no chão, e não recebem luz direta do sol. Esse sistema de produção de ovos foi proibido em toda a União Europeia no ano de 2012. No entanto, continua liberada a importação dos ovos produzidos no sistema de confinamento de outros países (Wallace, 2020).

Assim, consideramos que o desenvolvimento da tecnologia no capitalismo dirigiu-se à natureza, primeiramente sob uma relação de dominação e, posteriormente, sob uma relação de mecanização, que impede os animais humanos e não humanos de viverem sua condição natural, controlando através do domínio dos meios de produção, da ciência e da tecnologia todo o processo de criação e reprodução da vida na Terra. Portanto, o progresso tecnológico e científico, edificado sobre a ideologia da supremacia humana na sociabilidade capitalista, se dá em uma relação de dominação e superexploração da natureza e da força de trabalho com a finalidade de atender as demandas econômicas do processo produtivo.

Dessa maneira, compreendemos que,

[...] o desenvolvimento da história vai de par com o desenvolvimento das técnicas. A cada evolução técnica, uma nova etapa histórica se torna possível. [...] As técnicas se dão como famílias. Nunca, na história do homem, aparece uma técnica isolada; o que se instala são grupos de técnicas, verdadeiros sistemas. Um exemplo banal pode ser dado com a foice, a enxada, o ancinho, que constituem, num dado momento, uma família de técnicas. Essas famílias de técnicas transportam uma história, cada sistema técnico representa uma época. Em nossa época, o que é representativo do sistema de técnicas atual é a chegada da técnica da informação, por meio da cibernética, da informática, da eletrônica (SANTOS, 2018, pp. 24-25).

A humanidade se relaciona com a natureza, porque dessa conexão deriva sua existência. De modo que a forma e o conteúdo dessa relação estão definidos pelo modo produtivo e não somente pela vontade do ser social. Em uma sociedade hegemonicamente capitalista, a inter-relação ser social/natureza está orientada pela lógica da apropriação privada da riqueza socialmente produzida que determinam a 
direção das inovações tecnológicas, as condições de produção, a intensidade da exploração da força de trabalho, assim como a degradação da natureza. Isto posto, as perguntas que devemos fazer sobre o uso de uma determinada tecnologia são: qual a finalidade do uso? Ela corresponde às necessidades sociais? Sua utilização atende uma demanda social, produtiva, econômica capaz de melhorar a qualidade de vida da população? Quais consequências socioambientais são geradas ao longo do tempo? Qual nível de controle e monitoramento das interações com o meio?

E, "finalmente, argumentar que ciência e tecnologia podem solucionar todos os nossos problemas em longo prazo" é muito pior que acreditar em bruxas, já que tendenciosamente omite-se o devastador enraizamento social da ciência e da tecnologia atuais. Também nesse sentindo, a questão central não se restringe, a saber, se empregamos ou não a ciência e a tecnologia com a finalidade de resolver nossos problemas - posto que é óbvio que devemos fazê-lo -, mas se seremos capazes ou não de redirecioná-las radicalmente, uma vez que hoje ambas estão estreitamente determinadas e circunscritas pela necessidade da perpetuação do processo de maximização dos lucros. (MÉSZÁROS, 2011, p. 53).

Devemos, ainda, interrogar-nos sobre o que consiste às necessidades humanas? Sejam elas da fantasia ou do estômago, elas não são um desejo natural do ser social. Excluindo as necessidades vitais, todas as outras são construções históricas e sociais. Na sociedade capitalista, as necessidades sociais são conduzidas pela apropriação privada de todas as dimensões da vida humana. Natureza, homens, mulheres, comida, sexo, sentimentos, tudo se converte em mercadorias. E é sob essa perspectiva que a inter-relação humanidade e natureza torna-se objetificada, pautada pelo valor de troca das mercadorias. Por fim, é preciso pontuar que a produção científica "é uma escolha social, orientada no capitalismo pela acumulação do lucro e não pelas necessidades da liberdade humana" (MENEZES, 2016, p.40).

\section{Adoecimento socioambiental e agtonegócio}

A racionalidade capitalista compreende a natureza como um elemento passivo que se molda ao atendimento das necessidades sociais. O ser social que inventou o machado como ferramenta de trabalho não é o mesmo ser social que inventou o Iphone, assim como a própria natureza de hoje não é a mesma de séculos atrás. A natureza é elemento vivo e criativo, possuidor de uma lógica em si mesmo.

Um dos exemplos mais significativos dessa racionalidade é a utilização indiscriminada, pelo agronegócio, das tecnologias de transgenia e de agrotóxicos³. A ponto de questionarmos quais fatores são considerados na liberação ou proibição de um novo agrotóxico? Quais fatores são avaliados pela Agência Nacional de Vigilância Sanitária (ANVISA), Ministério da Agricultura, Pecuária e Abastecimento (MAPA) e Ministério do Meio Ambiente (MMA), na regulamentação ou proibição de um agrotóxico? Aspectos como aumento da qualidade de vida da população, mais acesso aos alimentos, redução dos custos de produção, diminuição da exploração da força de trabalho no campo, dentre outros, são levados em consideração? 
Se, sob uma perspectiva, o uso dos agrotóxicos e da transgenia aumentaram a produtividade agrícola, por outro, podemos nos perguntar sobre quais são os efeitos deste uso prolongado para a natureza e a sociedade. Pesticidas, fungicidas, praguicidas, biocidas, agroquímicos, produtos fitofarmacêuticos ou produtos fitossanitários, defensivos agrícolas são todos agrotóxicos. Substâncias químicas utilizadas na agricultura com o objetivo de eliminar qualquer outro ser vivo que interage ou que atrapalhe o crescimento do cultivo-alvo. Inventadas desde a Primeira Guerra Mundial como armas químicas, essas substâncias chegaram à agricultura por volta de 1960 com a Revolução Verde e são, desde então, consideradas como substâncias essenciais para o sucesso da produção agrícola. A necessidade de utilização dos agrotóxicos está tão arraigada na sociedade que o uso tem crescido mundialmente, chegando há um aumento de 100\% entre o período de 2000 a 2010 (BOMBARDI, 2017).

Em um estudo minucioso realizado pela pesquisadora Larissa Mies Bombardi (2017), a partir da análise de dados públicos oficiais ${ }^{4}$ que retratam a utilização dos agrotóxicos na agricultura brasileira, apontou-se que o país obteve um aumento de 135\% no consumo de agrotóxico, no período de 2000 a 2014. Houve um consumo de 170.000 toneladas de agrotóxicos no ano de 2000, chegando ao ano de 2014 com um consumo de 500.000 toneladas de agrotóxicos. Os dados analisados pela pesquisa demonstram que o aumento exponencial do consumo de agrotóxicos agrícolas está vinculado ao crescimento do plantio das monoculturas de soja, milho e cana de açúcar. Essas três culturas receberam $72 \%$ de todo agrotóxico utilizado no país. Elas servem, majoritariamente, para a produção de ração de animais de corte (gado, aves e suínos) e geração agroenergia (BOMBARDI, 2017).

Deste modo, fica perceptível que o padrão produtivo do agronegócio é o responsável direto pela maior parte do consumo dos agrotóxicos no Brasil. Isto, porém, não quer dizer que a produção de alimentos na agricultura familiar não utiliza agrotóxicos. Mas a questão que se coloca em análise é a perceptível diferença do consumo de agrotóxicos em cada tipo de agricultura. Questionamos ainda a indispensável aplicação dos agrotóxicos para a produção dos alimentos, diferentemente das commodities agrícolas.

Entre os anos de 2012 e 2016, houve um crescimento das áreas destinadas ao plantio da soja e cana de açúcar $(79 \%, 48 \%)$, e o decréscimo significativo das lavouras de arroz, feijão e mandioca, com taxas de redução de, respectivamente, $37,5 \%, 31 \%$ e $22 \%$. Arroz, feijão e mandioca são componentes básicos da alimentação brasileira e deveriam ser considerados produtos prioritários da agricultura nacional, para a garantia da segurança e soberania alimentar do país. No entanto, o Brasil vem aumentando a importação desses alimentos, sendo obrigado a importar, em 2015, para atendimento do consumo interno, 850 mil toneladas de arroz e 150 mil toneladas de soja (BOMBARDI, 2017).

A pesquisa de Bombardi (2017) apontou que $96,5 \%$ de toda a soja e $88,4 \%$ do milho brasileiros são transgênicos. A tecnologia da transgenia pode ser definida como uma modificação genética no DNA da planta, que busca introduzir um novo gene que não ocorre naturalmente na espécie. Na agricultura, essa tecnologia é utilizada para tornar as culturas resistentes à aplicação dos agrotóxicos, eliminando os inimigos naturais que atacam as lavouras. A produção agrícola em monoculturas, tende a sofrer com o 
ataque de outros seres vivos pelo fato de concentrar em um único espaço plantas de uma mesma espécie, diminuindo a capacidade de interação e/ou proteção natural das plantas com o meio ambiente. Além disso, as plantas estão mais susceptíveis a outros seres vivos, as monoculturas têm menos resistência às mudanças climáticas e adaptação ao meio, por serem sementes híbridas e/ou transgênicas que possuem baixa variabilidade genética. Desse modo, a utilização dos agrotóxicos está diretamente vinculada às sementes transgênicas, sendo indispensáveis para o seu crescimento (PINHEIRO MACHADO; MACHADO FILHO, 2014).

Os dados da pesquisa evidenciam a assimetria dos impactos, do uso e do ganho financeiro gerado com os agrotóxicos, quando se compara os números do Brasil com os países da União Europeia, que são os principais produtores de agrotóxicos. O uso de agrotóxicos pode ser, aparentemente, encarado de forma positiva, dado ao aumento da produtividade agrícola e a diminuição do trabalho empregado nas lavouras. Porém, a longo prazo, o aumento progressivo do uso dos agrotóxicos na agricultura tem contribuído com a intoxicação humana, a diminuição da fertilidade dos solos, a contaminação ambiental gerando um processo de adoecimento socioambiental (PIGNATI; MACHADO, 2011).

A situação é tão grave que, entre o período de 2007 e 2014, o Ministério da Saúde notificou 25.000 mil casos de intoxicação por agrotóxicos de tipo agrícola, números considerados subnotificados pelo próprio ministério. A estimativa real do MS é de 50 intoxicações para cada notificação, o que pode elevar a notificação de intoxicações para 1.250 .000 casos, o equivalente a mais de 1.7000 casos de intoxicação por ano (BOMBARDI, 2017). Esses números refletem o uso indiscriminado dos agrotóxicos na agricultura, tendo em vista a legislação permissiva do estado brasileiro em relação à liberação, uso e fiscalização dos agrotóxicos. Após a liberação do uso de determinado agrotóxico, não haverá, em nenhum momento, uma reavaliação sobre as consequências do seu uso em longo prazo. A venda dos agrotóxicos ocorre livremente no mercado agrícola. Qualquer cidadão com dinheiro consegue comprar e utilizar uma substância que pode intoxicar e contaminar o meio ambiente e até matar, como expressam os números abaixo:

[...] o início do governo do presidente Jair Bolsonaro (2019), 290 substâncias foram liberadas para utilização. A análise ainda revela que, deste número total, pelo menos $32 \%$ dos produtos já são proibidos em toda a União Europeia. O ritmo da aprovação dessa nova lista já é a maior em relação aos últimos anos. Em 2018, 229 produtos foram liberados entre janeiro e julho, totalizando 422 no ano, enquanto em 2017, foram 195 produtos no primeiro semestre e 405 no ano. O Brasil é considerado o maior consumidor de agrotóxicos do mundo em números absolutos. Um relatório divulgado pelo Instituto Brasileiro de Meio Ambiente (IBAMA) revelou que a agricultura brasileira chegou a usar 539,9 mil toneladas de pesticidas em 2017 (Agência Italiana de Notícias [ANSA], 2019, para. 3).

Desde 2007, mais de 12 mil pessoas tentaram suicídio com agrotóxicos em todo o Brasil. Dessas tentativas, 1.582 resultaram em mortes. Outras 231 tiveram cura, mas com sequelas. A maioria das tentativas de suicídio ocorreu no Paraná, com 2.140 registros. Em seguida vêm São Paulo e Pernambuco. Agrotóxicos agrícolas é a terceira substância mais comum em tentativas de suicídio no Brasil, atrás de medicamentos e produtos para matar ratos. A quantidade de pessoas que tentaram suicídio no 
Brasil com agrotóxicos é quase oito vezes maior do que a dos que adotam abuso de drogas ilícitas ou lícitas, como álcool e anfetaminas (FONSECA, 2018, para. 5).

Somada a isso, a principal técnica de aplicação dos agrotóxicos no Brasil é a pulverização por bombas de aplicação manual ou aviões. A pulverização aumenta a área de abrangência do agrotóxico além da cultura agrícola, contaminando o espaço ao redor das plantações, o solo, o lençol freático e todos os seres vivos que estão no raio de aplicação. Essa prática, além de aumentar a concentração dos agrotóxicos aplicados nas lavouras, agrava os índices de contaminação dos trabalhadores rurais (PIGNATI; MACHADO, 2011).

A técnica de pulverização dos agrotóxicos é tão danosa ao meio ambiente que a sua utilização foi proibida na União Europeia (UE), em 2009 (BOMBARDI, 2017). Os mesmos países que internamente criaram medidas de controle para o uso dos agrotóxicos em seus territórios nacionais, devido ao risco ambiental e social que o uso indiscriminado dessas substâncias pode gerar, são os maiores produtores de agrotóxico no mundo. Essa contradição inerente à reprodução capitalista, marcada pela relação de subordinação entre os países do centro com a periferia do capital, produz uma discrepância abissal quando checamos os dados de utilização dos agrotóxicos no Brasil com os países da UE.

A assimetria mostra-se ainda mais violenta quando comparamos as consequências sociais, ambientais e financeiras. Este é um traço predominante nas economias dependentes, a América Latina se especializou em perder. Perdemos no passado e continuamos perdendo no presente. A UE proibiu a utilização, em seu território, de $44 \%$ dos agrotóxicos que utilizamos em solo brasileiro, mas não proibiu a sua produção e venda para o mundo, dado ao fato que as duas maiores empresas deste mercado são alemãs: $1^{\circ}$ Syngenta (Suíça/China); $2^{\circ}$ Bayer CropScience (Alemanha); $3^{\circ}$ BASF (Alemanha).

O centro do capital vende para as economias dependentes, como o Brasil, "as tecnologias" que a sua população não pode consumir. Mesmo que, de forma contraditória, os agrotóxicos retornem ao seu solo de origem, através da exportação dos alimentos aqui produzidos. Interessa-nos desvelar a disparidade e o grau de violência empregado na relação do centro do capital com a periferia. Serão os trabalhadores rurais brasileiros mais resistentes à contaminação por agrotóxicos do que os trabalhadores da UE? Nossos rios, solo, abelhas estão livres desse tipo de contaminação? Por que cabe ao Brasil, na divisão internacional do trabalho e da produção de mercadorias, a função de produtor de matérias-primas?

Ao analisarmos o uso dos agrotóxicos como uma tecnologia significativa para o "sucesso" do agronegócio no Brasil, consideramos que é impossível, sob o domínio da produção capitalista, o desenvolvimento de "um possível uso racional" dessas substâncias. Como diminuir o uso dos agrotóxicos na agricultura capitalista se os técnicos extensionistas possuem metas de vendas? Tendo em vista que o crédito rural, acessado pelo agricultor familiar e o grande produtor rural, é repassado junto com o uso dos agrotóxicos? E que a venda é irrestrita e a fiscalização é restrita ao pequeno número de funcionários das instituições reguladoras? As respostas a estas perguntas já são velhas conhecidas nossas. O novo 
capitalismo do agronegócio continua velho. Segue incapaz de reproduzir sem gerar desigualdades sociais e destruição da natureza.

\section{Considerações finais}

A discussão sobre o desenvolvimento tecnológico e científico na produção capitalista, bem como a análise da cadeia produtiva da carne, da soja, e a utilização indiscriminada dos agrotóxicos ou de outros setores do agronegócio, apontam para a luta de classes intrínseca à escolha desse modelo produtivo. A luta de classes está na destruição da natureza, no adoecimento dos trabalhadores, na produção de alimentos com níveis elevados de agrotóxicos, na superexploração do trabalhador rural, na produção científica voltada para o lucro, no lucro exorbitante das transnacionais, nós conflitos agrários, ou seja, na produção destrutiva da natureza e no adoecimento socioambiental.

O progresso técnico-científico do agronegócio no Brasil é a síntese da produção da riqueza capitalista e do adoecimento socioambiental. Entretanto, ressaltamos que ao apontarmos as contradições do desenvolvimento tecnológico e científico da sociedade capitalista, tendo como objeto de análise o agronegócio, não nutrimos como esperança e estratégia de transformação social o retorno ao passado. A defesa idealista de retorno à uma vida idílica, com baixo desenvolvimento tecnológico, tende a significar, quase sempre na sociedade capitalista para os trabalhadores do campo e da cidade, mais horas de trabalho e menor produtividade (aumento da mais-valia absoluta), denotando maior exploração da sua força de trabalho.

A capacidade humana de transformar a natureza é também criadora e possibilitou conquistas e melhorias da qualidade de vida. Todavia, precisamos retirar desse debate a cortina de fumaça que encobre a realidade em que vivemos. A utopia de uma vida idilica, com condições arcaicas de técnica e tecnologia no processo de trabalho, ainda que possa ser a escolha de alguns, não pode ser encarada como a resolução das consequências socioambientais causadas pela agricultura capitalista. Tão pouco nos serve também o uso de uma tecnologia criada com a finalidade do lucro.

O modo de produção capitalista é progressivamente degradante da inter-relação sociedade e natureza, pois não existe um sentido próprio para as coisas produzidas, apenas somos impelidos a produzir e consumir mais, o sentido desta sociabilidade está no lucro e não na vida. Assim, recuperamos o significado da categoria metabolismo como chave de compreensão da totalidade em que vivemos. Fora dessa perspectiva de análise, que aponta a complexa relação entre sociedade e natureza, podemos correr o risco de reproduzir uma visão idealista sobre a natureza e a humanidade.

A luta ecológica alheia ao sofrimento humano, que idealiza uma natureza passiva aos maus tratos do progresso tecnológico da sociedade urbano-industrial, deve ser encarada como uma pacificação das contradições do sistema capitalista. Reciclar o lixo, escolher de forma consciente o que se consome, ainda que sejam ações individuais importantes, não podem ser encaradas como uma estratégia de superação da crise socioambiental que nos encontramos. 
Capitalismo sustentável é uma contradição nos termos, incapaz de se realizar. Em muitos casos, percebemos que a crítica ecológica à sociabilidade capitalista parte de um lugar comum, que busca salvar a natureza da exploração humana, abandonando a exploração do trabalho humano, o adoecimento do corpo e da alma, refundando a cisão humanidade/natureza. Esta perspectiva não ajuda a solucionar a problemática que vivemos - o ser humano e a natureza são explorados e coisificados, transformados em mercadorias.

Mas também consideramos reducionista a construção de lutas anticapitalistas alheias à degradação e o adoecimento socioambiental do planeta. As lutas anticapitalistas que se negam a ver a complexidade da luta de classes, na qual exploração da força de trabalho e da natureza caminham juntas, estão fadadas ao fracasso. A hostilidade das lutas ecológicas ao desenvolvimento da técnica e da tecnologia precisa ser combatida, assim como precisamos combater a ideologia do progresso industrial como a concepção universal de bem-estar social e de sociedade.

Portanto, a compreensão da questão socioambiental como parte da luta de classes na atualidade não deve ser encarada como um apelo ecologista às lutas dos trabalhadores ou com uma inserção da pauta "verde" aos movimentos anticapitalistas. A totalidade da produção capitalista "somente desenvolve a técnica e a combinação do processo de produção social na mesma medida em que destrói as fontes de toda a riqueza: a terra e os trabalhadores” (MARX, 2013, p. 703).

A pulsão acumulativa e expansionista do capital nos conduziu a uma catástrofe socioambiental, que MARX (2013) já anunciava em 1867, no Livro I d' O Capital como a "fratura irreparável do metabolismo social". De tal maneira, que a crise socioambiental revela, à sociedade, a contradição fundamental do capitalismo dada entre as condições de sua produção e reprodução.

Isto é, "o problema (a crise ecológica) é suficientemente concreto, independente do uso que dele se faz nos dias atuais (MÉSZÁROS, 2011, p. 52)”. Logo, se faz urgente a compreensão da encruzilhada que vivemos: a humanidade detém progressivamente tecnologias de extração e interferência na natureza, entretanto, é cada vez menor a capacidade humana de equilíbrio natural e mitigação dos impactos socioambientais. A produção capitalista integrou a humanidade numa lógica universal de tal forma que, se no passado o sistema foi capaz de, paradoxalmente, produzir avanços técnicos e tecnológicos melhorando a qualidade de vida da população e, ao mesmo tempo, aumentando os níveis de exploração da força de trabalho, na atualidade a capacidade destrutiva do capitalismo é superior à sua capacidade de produzir coisas úteis ao presente e ao futuro da humanidade. Se no passado os colapsos civilizatórios atingiram uma escala regional e/ou local, não podemos dizer o mesmo sobre o futuro (MARQUES, 2016).

Consideramos que a crise socioambiental é, em nosso tempo histórico, a questão política concreta. Superar a cisão entre as lutas ecológicas e as lutas pela emancipação humana é, portanto, uma empreitada imprescindível. Apartadas, essas lutas perdem a capacidade de mobilização e transformação social. Pois a crise econômica e o adoecimento socioambiental não são um objeto ou fato social, trata-se de um processo com ritmos e intensidades diferentes (MARQUES, 2016). 
A atividade humana possui uma capacidade e uma finalidade dialética de interação com a natureza, capaz de nutri-la, mas também de destruí-la, tal qual a existência da vida humana na Terra. Como seres sociais e naturais, não só afetamos a natureza, mas também somos afetados por ela, sendo a interação metabólica entre sociedade e natureza a chave de compreensão da totalidade em que vivemos. Não haverá superação do capitalismo como modo produtivo e do capital como relação social, sem a transformação da forma como o ser social se relaciona com a natureza, isso implica na supra-sunção da exploração capitalista da força de trabalho humana.

\section{Referências:}

Agência Italiana de Notícias Brasil. (2019, 23 julho). Governo Bolsonaro libera 51 agrotóxicos e totaliza 290 no ano. Época Negócios. Disponível em:

https://epocanegocios.globo.com/?status=404\&url=https://epocanegocios.globo.com/Brasil/noticia/20 19/07/governo-bolsonaro-libera-51-agrotoxicos-e-totaliza-290-no-ano.html. Acesso em: 12 fev.2021.

BOMBARDI, Larissa Mies. Geografia do uso de agrotóxicos no Brasil e conexões com a União Europeia. São Paulo: Laboratório de Geografia Agrária, FFLCH - USP, 2017.

BBC News Brasil. (2018, 28 agosto). FELLET, João. As silenciosas mortes de brasileiros soterrados em armazéns de grãos. Disponível em: https://www.bbc.com/portuguese/brasil-45213579. Acesso em: 12 jan.2021.

FOSCESA, Bruno. (2018, 6 agosto). 26 mil brasileiros foram intoxicados por agrotóxicos desde 2007. UOL, Meio ambiente. Disponível em: https://noticias.uol.com.br/meio-ambiente/ultimasnoticias/redacao/2018/08/06/numeros-da-intoxicacao-por-agrotoxico-nobrasil.htm\#: :text $=$ Cerca $\% 20 \mathrm{de} \% 2040 \% 20$ mil $\% 20$ pessoas, dados $\% 20 \mathrm{do} \% 20 \mathrm{Minist} \% \mathrm{C} 3 \% \mathrm{~A} 9 \mathrm{rio} \% 20 \mathrm{da} \%$ 20Sa $\%$ C3\%BAde. Acesso em: 15 mar.2021.

International Pollutants Elimination Network; Associação Brasileira de Saúde Coletiva (2021). Agronegócio e pandemia no Brasil uma sindemia está agravando a pandemia de COVID-19? Disponível em: https://www.abrasco.org.br/site/wp-content/uploads/2021/05/Agronegocio- ABrasco-IPEN.pdf. Acesso em: 20 ago.2021.

Instituto Brasileiro de Geografia e Estatística (2020). Números do Censo 2020. Disponível em: https://censo202fonse0.ibge.gov.br/sobre/numeros-docenso.html\#: : :text $=\mathrm{N} \% \mathrm{C} 3 \% \mathrm{BAmeros} \% 20 \mathrm{do} \% 20 \mathrm{Censo} \% 202020 \&$ text $=$ Veja $\% 2 \mathrm{C} \% 20 \mathrm{a} \% 20$ seguir $\% 2 \mathrm{C}$ \%20algumas $\% 20$ informa $\% \mathrm{C} 3 \% \mathrm{~A} 7 \% \mathrm{C} 3 \% \mathrm{~B} 5$ es, $\mathrm{a} \% 20$ serem $\% 20$ visitados $\% 2 \mathrm{C} \% 205570 \% 20$ munic $\% \mathrm{C} 3 \% \mathrm{~A}$ Dpios. Acesso em: 06 mar.2021.

Intergovernmental Painel on Climate Change (2019). Climate Change and Land: an IPCC special report on climate change, desertification, land degradation, sustainable land management, food security, and greenhouse gas fluxes in terrestrial ecosystems. In: 50th Session of the Intergovernmental Panel on Climate Change. Summary for Policymakers (SPM). Disponível em: https://www.ipcc.ch/srccl/. Acesso em: 07mar.2021.

LUKÁCS, György. (s.d). O trabalho. In: LUKÁCS, G. Por uma ontologia do ser social. I. Tonet (Trad.). Disponível em:

http://afoiceeomartelo.com.br/posfsa/Autores/Lukacs, \%20Georg/O\%20TRABALHO \%20\%20traducao \%20revisada.pdf. Acesso em: 09 set.2020.

MARCATTI, A. A. Labor da carne: o trabalho em um frigorífico de aves. 2014. 132p. Dissertação (Mestrado em Educação) - Faculdade de Educação, Universidade Federal de Minas Gerais, Belo Horizonte, 2014.

MARQUES, Luiz. Capitalismo e colapso ambiental. 2 ed. Campinas: Editora da Unicamp, 2016. 
MARX, Karl. Manuscritos econômico-filosóficos. J. Raniere (Trad.). São Paulo: Boitempo, 2004.

MARX, Karl. O capital: crítica da economia política. R. Enderle (Trad.). (Livro I: O processo de produção do capital). São Paulo: Boitempo, 2013.

MENEZES, Antonio Julio. Movimentos sociais e educação: o MST e o Zapatismo entre a autonomia e a institucionalização. São Paulo: Alameda, 2016.

MÉSZÁROS, István. A crise estrutural do capital. 2 ed. F. Cornejo (Trad.). São Paulo: Boitempo, 2011.

PIGNATI, W. A.; MACHADO, J. M. H. O agronegócio e seus impactos na saúde dos trabalhadores e da população do estado de Mato Grosso. In: GOMEZ, C. M.; MACHADO, J. M. H.; PENA, P. G. P. (Orgs.). Saúde do trabalhador na sociedade brasileira contemporânea. Rio de Janeiro: Editora Fiocruz, 2011. p.245-272.

PINHEIRO MACHADO, L. C.; MACHADO FILHO, L. C. P. Dialética da agroecologia. São Paulo: Expressão Popular, 2014.

SANTOS, Milton. Por uma outra globalização: do pensamento único à consciência universal. 28 ed. Rio de Janeiro: Record, 2018.

SOUZA JUNIOR, Hormindo Pereira de. Centralidade ontológica do trabalho ou centralidade da informação e do conhecimento nos processos de formação humana? Pro-Posições v.19 n.2 Campinas maio/ago. 2008 - Disponível em: https: / www.scielo.br/scielo.php?script=sci_arttext\&pid $=$ S0103-73072008000200012\&lng=pt\&nrm $=$ iso Acesso em 21 mar.2021.

Wallace R. Pandemia e agronegócio: doenças infecciosas, capitalismo e ciências. São Paulo: Elefante, 2020.

\begin{abstract}
Notas
${ }^{1}$ Doutora (2020) e Mestre (2014) em Educação e Inclusão Social pela UFMG. Graduada em Zootecnia pela UFMG (2011) e Pedagogia pela UFOP (2018). Pesquisadora vinculada ao Grupo de Estudos e Pesquisa Marx, Trabalho e Educação, vinculado ao Núcleo de Estudos sobre Trabalho e Educação (NETE/FaE) e membro do Núcleo de Estudos e Pesquisa em Territórios, Educação Integral e Cidadania - TEIA/UFMG. Currículo Lattes: http://lattes.cnpq.br/3269515060212413. Orcid: https://orcid.org/0000-0002-6858-4589. E-mail: amanda.apmarcatti@gmail.com.

2 Pós-Doutorado em Filosofia Política e Educação pela Universidade Federal Fluminense. Doutor em História e Filosofia da Educação pela Pontifícia Universidade Católica de São Paulo. Mestre em Educação pela UFMG. Bacharel e licenciado em Ciências Sociais pela Universidade Federal de Minas Gerais. Professor Associado da UFMG. Professor do Programa de PósGraduação Conhecimento e Inclusão Social em Educação da FAE-UFMG. Currículo Lattes: http://lattes.cnpq.br/4152804305418122. Orcid: https://orcid.org/0000-0001-9411-6802. E-mail: hormindojunior@gmail.com.

${ }^{3}$ É importante considerarmos que o debate sobre a tecnologia da transgenia possui um caráter complexo de discussão sobre as suas contribuições e consequências. Deste modo, o presente artigo se debruça sobre um aspecto do uso da tecnologia da transgenia no contexto da produção agrícola do agronegócio, ou seja, a sua correlação com a utilização indiscriminada dos agrotóxicos na agricultura capitalista e as consequências socioambientais geradas com este uso, cabendo, portanto, outras perspectivas de análise.

${ }^{4}$ Os dados foram produzidos e publicados por: Sistema Nacional de Informações Tóxico Farmacológicas (SINITOX), IBGE, IBAMA, Companhia Nacional de Abastecimento (CONAB), Ministério do Desenvolvimento Social (MDS), Ministério da Saúde (MS), MAPA, MMA, Sistema de Informação de Agravos de Notificação (SINAN) e ANVISA.
\end{abstract}

